\title{
Molecular aspects of skin aging. Literature review
}

\author{
Molekularne aspekty fotostarzenia. Przegląd piśmiennictwa
}

Michał Rogowski-Tylman, Joanna Narbutt, Anna Woźniacka, Aleksandra Lesiak

Department of Dermatology and Venereology, Medical University of Lodz, Lodz, Poland

Przegl Dermatol 2016, 103, 139-142 DOI: 10.51 |4/dr.2016.59136

\section{KEY WORDS:}

skin aging, metalloproteinases, cathepsin K, progerin, transforming growth factor- $\beta$ / Smad pathway.

SŁOWA KLUCZOWE:

fotostarzenie, metaloproteinazy, katepsyna K, progeryna, ścieżka TGF- $\beta /$ Smad.

\section{ADDRESS FOR} CORRESPONDENCE:

Michał Rogowski-Tylman MD Department of Dermatology and Venereology

Medical University of Lodz pl. Hallera 1

90-647 Lodz, Poland

Phone: +48 512088404

E-mail: rogowski.tylman@ gmail.com

\begin{abstract}
Skin aging is a complex process composed of sequential phenomena which lead to structural and functional changes. There are many pathways leading to photoaging, but their mechanisms are not well elucidated. Matrix metalloproteinases are a family of proteases known to degrade collagen. Aged skin is accompanied by higher metalloproteinase production, leading to degradation of extracellular matrix. Another pathway of aging is the complex TGF- $\beta /$ Smad. Transforming growth factor $\beta$ is the primary regulator of collagen synthesis in skin. It has been reported that UV irradiation impairs TGF- $\beta / S m a d$ signaling through downregulating the transcription. In recent literature cathepsins and progerin are the newest proteins reported to be involved in aging. Cathepsins are a group of proteases with collagenolytic and elastinolytic activities, but their role in photoaged skin is only partially known. Progerin is an abnormal form of lamin A. In recent studies, it is noted for its participation in the process of skin photoaging.
\end{abstract}

\section{STRESZCZENIE}

Proces fotostarzenia skóry polega na występowaniu sekwencyjnych zjawisk, które prowadzą do stopniowych zmian w jej strukturze i funkcji. Znanych jest wiele ścieżek uszkodzenia skóry, jednak wciąż nie są one w pełni poznane. Enzymami proteolitycznymi, które mają zdolność degradacji kolagenu i włókien elastycznych, są metaloproteinazy. Ich aktywność jest modulowana głównie przez tkankowe inhibitory, a indukcja ekspresji pod wpływem promieniowania ultrafioletowego jest jednym z głównych zjawisk patogenetycznych fotostarzenia. W badaniach stwierdzono istotny udział transformującego czynnika wzrostu $\beta$ (TGF- $\beta$ ) w nasileniu syntezy kolagenu. W starzejącej się skórze obserwuje się zmniejszenie syntezy kolagenu poprzez uszkodzenie ścieżki sygnału TGF- $\beta$ /Smad. Katepsyny są grupą proteaz o właściwościach kolageno- i elastolitycznych. Zaangażowane są w mechanizmy regulacyjne, a ich rola $\mathrm{w}$ fotostarzeniu nie jest do końca poznana. Zmutowana forma laminy A - progeryna - zaburza kształt jądra komórkowego i proliferację. Powoduje progerię, a także stwierdzono jej udział $\mathrm{w}$ procesach fizjologicznego starzenia. 


\section{INTRODUCTION}

Skin aging is a complex process composed of sequential phenomena which eventually lead to structural and functional changes of tissue. The consequence is loss of all the adaptive and protective mechanisms of the organisms and development of various diseases such as neoplasms. Aging is a genetically determined process; however, epigenetic and environmental factors, such as UV radiation (UVR) [1], xenobiotics, mechanical stress, hormonal changes, and metabolic processes (generation of reactive chemical compounds, e.g. activated oxygen species, sugars, and aldehydes), also play an important role in its pathogenesis. These factors lead together to cumulative structural and physiological alterations and progressive changes in each skin layer as well as changes in skin appearance, especially on sun-exposed areas [2].

Aging is divided into extrinsic and intrinsic types. The main factor responsible for extrinsic aging of the skin is UVR. UV-induced skin aging or photoaging is defined as the premature occurrence of signs of aging on the skin. It presents with characteristic morphological changes of both the epidermal and dermal compartment [3]. UV radiation has many harmful effects on the human organism including skin burn, suppression of immunity, skin photodamage and cancer development [4]. Skin erythema, burn or even suppression of immunity occur a short time after skin exposure to UVR whereas cancers or photodamage develop even many years after overexposure to UVR, and especially the cumulative dose of UVR is important. UVR irradiation causes collagen alteration by two mechanisms including direct collagen breakdown and inhibition of procollagen biosynthesis [5]. Single exposure of skin to an erythemal UVR dose causes complete loss of procollagen synthesis which persists for $24 \mathrm{~h}$ and recovery occurs after $72 \mathrm{~h}$.

\section{METALLOPROTEINASES}

Extracellular matrix is mainly composed of collagen I and III, elastin, proteoglycans and fibronectin. In skin exposed to UVR we can observe disorganization of collagen fibers and deposits of impaired elastin. Additionally there is a decreased amount of collagen I and III precursors and an increased amount of elastin. The dermo-epidermal junction is flattened and its function is also impaired [6].

Matrix metalloproteinases (MMPs) are proteolytic enzymes which have the ability to degrade collagen, elastic fibers and other proteins located within connective tissue. Their biological activity is modulated mainly by tissue inhibitors of matrix metalloproteinases (TIMP) [7]. MMPs are classified as collagenas- es, gelatinases, stromelysins and membrane-type MMPs. MMPs are involved in many physiological and pathological proteolytic events including embryogenesis, wound healing, inflammation, angiogenesis and cancer [8]. In numerous studies it has been shown that skin exposure to UVR induces expression mainly of three metalloproteinases: collagenase, 92-kd gelatinase and stromelysin 1 [9]. These proteins are able to completely degrade dermal collagen. The process is initiated by MMP-1, and when collagen is cleaved it is further degraded by elevated levels of MMP-3 and MMP-9 [10].

It was also shown that $24 \mathrm{~h}$ after UVR irradiation expression of MMP-8 and MMP-12 is present in human skin as a result of influx of neutrophils and macrophages from the circulation. Taking all data together, the studies clearly suggest that MMP-1, MMP-3 and MMP-9 are primary UV-inducible collagenolytic enzymes initiating degradation of fibrillar collagens in human skin [11].

\section{TGF- $\beta /$ SMAD PATHWAY}

Transforming growth factor $\beta$ (TGF- $\beta$ ) is the name given to a family of multifunctional polypeptides which consists of three almost homologous isoforms: TGF- $\beta 1,-2,-3$. They play a key role in controlling cellular differentiation and growth. Transforming growth factor $\beta$ inhibits cell division of most epithelial cells, and stimulates proliferation of fibroblasts and synthesis of extracellular matrix components such as elastin, collagen and laminin. In addition, TGF- $\beta$ is an immunosuppressive cytokine with marked inhibitory effects on T, B and NK cells. Transforming growth factor $\beta$ has been shown to stimulate expression of specific integrins (superfamily of heterodimeric extracellular matrix receptors) which are required to switch keratinocytes from the differentiating to a regenerative phenotype [12-15].

UVA and UVB can stimulate and inhibit the production of growth factors for melanocytes [16]. It was shown that UVA and UVB can stimulate TGF- $\beta$ in fibroblasts, which suggests that stroma cells in the dermis may be involved in the UV-mediated activation of cells and promote skin tumor development. Several alterations in skin connective tissue that occur during aging are mediated by mechanisms that are similar to those occurring in response to UV irradiation [17]. Thus, skin aging is associated with increased MMP expression, impaired TGF- $\beta$ signaling, enhanced collagen degradation, and decreased collagen synthesis. Literature data indicate that UV irradiation blocks cellular responsiveness to TGF- $\beta$ through two mechanisms that impair TGF- $\beta$ receptor function. The primary mechanism is down-regulation of TGF- $\beta$ RII, and the secondary mechanism 
is induction of Smad7. UV irradiation impairs the TGF- $\beta$ /Smad pathway and leads to reduction of type I pro-collagen production in adult human skin fibroblasts [18]. UVR impairs the TGF- $\beta /$ Smad pathway through transcriptional down-regulation of TRII, and this impairment is primarily responsible for reduced procollagen synthesis in human skin fibroblasts [19].

\section{CATHEPSIN K}

Cathepsins are a group of papain-cystein proteases with collagenolytic and elastinolytic activities that are involved in various aspects of extracellular matrix turnover. Several cathepsins, including cathepsins L, K and G, have been described to be expressed in skin or skin-derived cells [20].

Cathepsin K depredates collagen and extracellular matrix. Under normal conditions it is involved in bone resorption by osteoclasts. Recent data indicate the role of this protein in degradation processes in many organs including skin. In single papers it was revealed that increased expression of cathepsin $\mathrm{K}$ occurs during cicatrisation, skin photodestruction and tumors [21, 22]. Other studies showed that cathepsin $\mathrm{K}$ is mainly expressed in BCC tumor adjacent tissue and, only in invasive forms of BCC, its expression may also be observed in tumor cells. This phenomenon may be responsible for tissue infiltration and rare metastasis. Studies performed in vitro in fibroblast culture showed the role of UVR in modulation of cathepsin $\mathrm{K}$ activity with subsequent degradation of extracellular matrix. Immunostaining of cultured skin fibroblasts incubated with labeled elastin demonstrated internalization of extracellular elastin to lysosomes and its degradation by cathepsin K. Induction of its expression in fibroblasts was observed both in vitro and in vivo after exposure to long-wave UVA. In contrast to fibroblasts from young donors, cells from old donors failed to activate cathepsin $\mathrm{K}$ in response to UVA [23]. These data suggest a role of intracellular elastin degradation by cathepsin $\mathrm{K}$ in the formation of solar elastosis [24].

\section{PROGERIN}

The studies on genetically conditioned Hutchinson-Gilford syndrome (progeria) showed the presence of a mutated form of lamin A (the main protein of nuclear matrix), progerin, which leads to deformation of nucleus shape and impairment of cell proliferation $[25,26]$. In young healthy subjects progerin expression is observed in papillary dermis and around the basement membrane zone, while in elderly subjects its expression is also presented in reticular dermis. This is the reason why progerin expression may be as- sessed as a molecular marker of physiological skin destruction. Accumulation of progerin has been shown to affect many aspects of cellular damage responses, including DNA repair and damage signaling [27].

Progerin accumulates in nuclear lamina during the differentiation of keratinocytes in aged skin and contributes to the delocalization of heterochromatin clusters away from the nuclear periphery, thereby contributing to genomic reorganization and causing the clinical sequelae that characterize old age [26]. In the study performed in vitro by Takeuchi and Rünger [26] it was demonstrated that fibroblasts from older donors exposed to UVR accumulated more nuclear progerin than neonatal fibroblasts. It has also been shown that exposure to UVA, but not UVB, induces progerin expression in neonatal and aged fibroblasts. Progerin intensity and distribution differ with age. In our study (data not shown), its distribution was similar in the elderly people and those after 1 week's exposure to UVR. These data suggest a new pathway of photoaging. We have shown that 1 week's sun exposure in healthy individuals is enough to significantly increase expression of the protein in human dermis.

As progerin appears to be a cellular aging biomarker for dermal fibroblasts and keratinocytes of normal individuals, so we may suspect that Hutchinson-Gilford progeria syndrome (HGPS) may indeed be a useful model of physiological aging. Strategies already tested on HGPS cells, such as farnesyl transferase inhibitors, might be useful in preventing normal aging and possibly slowing progression of age-related pathologies [28].

\section{CONCLUSIONS}

Photoaging is a complex process determined both by genetic and environmental factors. Ultraviolet radiation (UVA and UVB) plays a very important role in premature skin aging as it can modulate expression of various proteins such as metalloproteinases, cathepsin, TGF- $\beta$ and progerin, which in consequence leads to rebuilding of extracellular matrix with predominant degradation of collagen. New strategies of prevention of photoaging should focus on maintaining the balance between specific proteins and restoring collagen deposits.

\section{ACKNOWLEDGMENTS}

The study was funded by the National Center of Science grant no. 2012/05/B/NZ5/01885 and Medical University of Lodz, project no. 503/1-152-01/503-01.

\section{Conflict of interest}

The authors declare no conflict of interest. 


\section{References}

1. Rittié L., Fisher G.J.: Natural and sun-induced aging of human skin. Cold Spring Harb Perspect Med 2015, 5, 89-96.

2. Mine S., Fortunel N.O., Pageon H., Asselineau D.: Aging alters functionally human dermal papillary fibroblasts: a new view of skin morphogenesis and aging. PLoS One 2008, 3, 99-105.

3. Yaar M., Gilchrest B.A.: Ageing and photoageing of keratinocytes and melanocytes. Clin Exp Dermatol 2001, 26, 583-591.

4. Quan T., Quin Z., Xia W., Shao Y., Voorhees J.J., Fisher G.J.: Matrix degrading metaloproteinases in photoaging. J Invest Dermatol 2009, 130, 20-24.

5. Duffy M.J., Maguire T.M., Hill A., McDermott E., O'Higgins N.: Metalloproteinases: role in breast carcinogenesis, invasion and metastasis. Breast Cancer Res 2000, 2, 252-257.

6. Xia W., Quan T., Hammerberg C., Voorhees J.J., Fisher G.J.: A mouse model of skin aging: fragmentation of dermal collagen fibrils and reduced fibroblast spreading due to expression of human matrix metalloproteinase-1. J Dermatol Sci 2015, 78, 79-82.

7. Van Doren S.R.: Matrix metalloproteinase interactions with collagen and elastin. Matrix Biol 2015, 44, 234-241.

8. Yamauchi M., Prisayanh P., Haque Z., Woodley D.T.: Collagen cross-linking in sun-exposed and unexposed sites of aged human skin. J Invest Dermatol 1991, 97, 938-941.

9. Massague J.: TGF-beta signal transduction. Annu Rev Biochem 1998, 67, 753-791.

10. Massague J., Chen Y.G.: Controlling TGF-beta signalling. Genes Dev 2000, 14, 627-644.

11. Massague J., Wotton D.: Transcriptional control by the TGF-Smad signaling system. EMBO J 2000, 19, 1745-1754.

12. Piek E., Heldin C.H., Dijke P.: Specificity, diversity, and regulation in TGF-beta superfamily signaling. EMBO J 1999, 13, 2105-2124.

13. Brenner M., Degitz K., Besch R., Berking C.: Differential expression of melanoma-associated growth factors in keratinocytes and fibroblasts by ultraviolet $\mathrm{A}$ and ultraviolet B radiation. Br J Dermatol 2005, 153, 733-739.

14. Fisher G.J., Voorhees J.J.: Molecular mechanisms of photoaging and its prevention by retinoic acid: ultraviolet irradiation induces MAP kinase signal transduction cascades that induce AP-1-regulated matrix metalloproteinases that degrade human skin in vivo. J Invest Dermatol 1998, 111, 61-68.

15. Quan T., He T., Voorhees J., Fisher G.: Ultraviolet irradiation blocks cellular responses to transforming growth factor-by down-regulating its type-II receptor and inducing Smad7. J Biol Chem 2001, 276, 2635-2649.

Received: 7V 2015

Accepted: 8 II 2016
16. Quan T., He T., Kang S., Voorhees J., Fisher G.: Solar ultraviolet irradiation reduces collagen in photoaged human skin by blocking transforming growth factor-beta type II receptor/Smad signaling. Am J Pathol 2004, 165, 741-751.

17. Chapman H.A., Riese R.J., Shi G.P.: Emerging roles for cysteine proteases in human biology. Ann Rev Physiol 1997, 59, 63-88.

18. Rao Q., Wang Y., Xia Q.Y., Shi S.S.: Cathepsin K in the immunohistochemical diagnosis of melanocytic lesions. Int J Clin Exp Pathol 2014, 7, 1132-1139.

19. Khalkhali-Ellis Z., Hendrix M.J.: Two faces of cathepsin D: physiological guardian angel and pathological demon. Biol Med 2014, 6, 345-354.

20. Sage J., De Quéral D., Leblanc-Noblesse E., Kurfurst R., Schnebert S., Perrier E., et al.: Differential expression of cathepsins $\mathrm{K}, \mathrm{S}$ and $\mathrm{V}$ between young and aged Caucasian women skin epidermis. Matrix Biol 2014, 33, 41-46.

21. Codriansky K., Quintanilla-Dieck M., Gan S., Keady M., Bhawan J., Runger T.: Intracellular degradation of elastin by cathepsin $\mathrm{K}$ in skin fibroblasts - a possible role in photoaging. Photochem Photobiol 2009, 85, 1356-1363.

22. Cao K., Capell B., Erdos M.R., Djabali K., Collins F.S.: A Lamin A protein isoform overexpressed in Hutchinson-Gilford progeria syndrome interferes with mitosis in progeria and normal cells. Proc Nat Acad Sci 2007, 104, 4949-4954.

23. Pacheco L.M., Gomez L.A., Dias J., Ziebarth N.M., Howard G.A., Schiller P.C.: Progerin expression disrupts critical adult stem cell functions involved in tissue repair. Aging 2014, 6, 1049-1063.

24. Musich P.R., Zou Y.: Genomic instability and DNA damage responses in progeria arising from defective maturation of prelamin A. Aging 2009, 1, 28-37.

25. Shumaker D.K., Dechat T., Kohlmaier A., Adam S.A., Bozovsky M.R., Erdos M.R., et al.: Mutant lamin A leads to progressive alterations of epigenic control in premature aging. Proc Nat Acad Sci 2006, 103, 8703-8708.

26. Takeuchi H., Rünger T.M.: Long-wave UV light induces the aging-associated progerin. J Invest Dermatol 2013, 133, 1857-1862.

27. Mc Clintock D., Ratner D., Lokuge M., Owens D.M., Gordon L.B., Collins F.S., et al.: The mutant form of lamin A that causes Hutchinson-Gilford progeria is a biomarker of cellular aging in human skin. PLoS One 2007, 2, 1-10.

28. Yang S.H., Meta M., Qiao X., Frost D., Bauch J., Coffinier C., et al.: A farnesyltransferase inhibitor improves disease phenotypes in mice with a Hutchinson-Gilford progeria syndrome mutation. J Clin Invest 2006, 116, 2115-2121. 